\title{
Technetium Tc-99m Tetrofosmin
}

National Cancer Institute

\section{Source}

National Cancer Institute. Technetium Tc-99m Tetrofosmin. NCI Thesaurus. Code C87410

A radiopharmaceutical consisting of tetrofosmin, composed of two bidentate diphosphine ligands chelating the metastable radioisotope technetium Tc-99 (99mTc), with potential imaging activity upon SPECT (single photon emission computed tomography). Upon administration, technetium Tc $99 \mathrm{~m}$ tetrofosmin is preferentially taken up by, and accumulates in, myocardial cells. Upon imaging, myocardial cells can be visualized and changes in ischemia and/or perfusion can be detected. 